DOI: $10.20472 / T E .2018 .6 .1 .002$

\title{
SCHOOL-BASED SOCIAL PEDAGOGY AND ITS IMPLEMENTATION IN THE CZECH SCHOOL SYSTEM
}

\section{JITKA LORENZOVA}

\begin{abstract}
:
The article aims to showcase the complicated, unfinished process of the implementation of social pedagogy and pedagogues into the practice of Czech schools, outlining the concept of social pedagogy along with its position in the international context. The focus of the text is the process of introducing social pedagogues into Czech schools over the past two decades. It describes the role of various projects that have supported the implementation of this new post, the activities of the academic community in attempting to influence legislation to include social pedagogues, as well as the viewpoints of the decision-making sphere. Risks to the aforementioned process are identified in the conclusion: legal reforms of the Act on Pedagogical Workers being blocked, fears of the financial burden resulting from the establishment of a new professional post within the school system, low awareness among school management of the kind of work social pedagogues do, unclear qualification requirements for social pedadogues, and finally competition between the Ministry of Education and the Ministry of Social Affairs over which of them should be in charge of the process.
\end{abstract}

\section{Keywords:}

social pedagogy, social pedagogue, school social work, school, socialization

JEL Classification: 121

\section{Authors:}

JITKA LORENZOVA, Charles University, Prague, Czech Republic, Faculty of Arts, Department of Education, Czech Republic, Email: jitka.lorenzova@post.cz

\section{Citation:}

JITKA LORENZOVA (2018). School-based social pedagogy and its implementation in the Czech school system . International Journal of Teaching and Education, Vol. VI(1), pp. 21-35., 10.20472/TE.2018.6.1.002 


\section{Introduction}

Since the Enlightenment, schools have comprised a necessary part of the process of normalization and discipline in modern societies. By raising citizens who are willing to participate in social life, schools have contributed to social cohesion. In our contemporary era characterized by the pluralization and fragmentation of social life, schools no longer prepare students for life in societies with clear and unchanging social stratification, cultural codes and symbolic representations, but for life in a changeable, ambivalent and culturally as well as socially diverse world. The social role of the school will increasingly depend on how well it fulfills its function of social integration.

Problems in social reality do not remain safely outside the gates of the school, but influence the educational processes and interactions happening there. Teachers are ordinarily not sufficiently prepared for the complexity of the solutions required. The school is also the environment that lays the foundations for success in life, and likewise the lack thereof. It is thus necessary to detect the problems that negatively influence everyday life at school early, and to solve them without making a drastic impact on the life of the child affected. This mission can be greatly positively aided by the practice of school social pedagogy, which has long been established in some countries (such as Germany and Poland) and dynamically evolved in the past few decades in others (the UK, Russia, Switzerland, Slovakia). In the Czech Republic, the process of introducing social pedagogy into schools has been met with a number of difficulties related to the unclear professional position of social pedagogues, despite the dynamic development of the field in the past quarter of a century.

\section{Goals and Methodology of the Study}

This article ranks among a number of studies that, inspired by a global interest in social pedagogy, map out the development of this field as a science and a professional practice in various countries (see Kornbeck and Rosendal Jensen, 2009, 2012; Kornbeck and Úcar, 2012; Petrie, 2013; Kyriacou et. al., 2009, Hegstrup, 2003, Hämäläinen and Eriksson, 2016). Considering the rising interest in the methods of social pedagogy in school practice in the past few decades, while also remaining aware of the fact that Czech social pedagogy has not established itself sufficiently in the international context so far, this article aims to provide the academic public with an overview of the implementation of social pedagogy, along with the profession of the social pedagogue, into the practice of Czech schools.

The study first expands on the concept of social pedagogy, followed by examples of several European countries where school social pedagogy and its practice have enjoyed an increase in public interest. The focus of the text is the process of introducing the profession of the social pedagogue into Czech schools throughout the past two decades. The conclusion discusses the risks currently present in this unfinished process. The 
article's methodology is based on an analysis of academic literature and other relevant documents, with the goal of making the current knowledge systematic and interpreting it from the point of view of social pedagogy.

\section{The Evolution of the Social Pedagogy Concept: A Summary}

As a science and as a professional practice, social pedagogy developed in the cultural context of Germany during the course of the $19^{\text {th }}$ and early $20^{\text {th }}$ centuries. Initially it had two main tendencies. The first was the intention to improve the social situation of the poor and needy by pedagogical means, particularly education and public service, in the tradition of Pestalozzi, Diesterweg and Fröbel. The second tendency was the effort of neo-Kantian philosophers to revive the platonic intellectual tradition while emphasizing the importance of the social dimension of education. According to this philosophical school, exemplified by P. Natorp, this social dimension had long been overlooked in the established Herbartian school of pedagogy, which was oriented towards the individual.

Between the two world wars, during the democratic Weimar Republic, a third tendency came to the forefront. Social pedagogy came to be understood as the state's care for children and youth who were at risk of neglect in their upbringing. An ambitious bill was passed, thanks to significant efforts by feminist campaigner G. Bäumer, then Minister for Social Policy, which made it possible for the Youth Office to order foster care (Fürsorgeerziehung) for children whose families did not perform their educational and social roles.

In 1929, the fifth edition of the Manual of Pedagogy was published, edited by $\mathrm{H}$. Nohl and T. Pallat. This edition was in fact called Social Pedagogy. Here Bäumer defines social pedagogy, possibly to bolster the new legislation, as a provision for educational upbringing by the state made available to children and young people outside the school and the family (Bäumer in Nohl \& Pallat, 1929). The field of social pedagogy was thus finally established, the culmination of a quarter of a century of development (Münchmeier \& Peukert in Böhnisch, 1997, 23-24). This begs the question: when and how can we even speak of social pedagogy in schools?

\section{The Practice of Social Pedagogy in Schools in the International Context}

In Germany, the homeland of social pedagogy, school-based social pedagogy began to develop under the influence of the North American model of school social work, imported into Europe in the 1960s and 70s. As articulated by Tillmann $(1980,1982)$, school social work is not an institution that could be definitively described, but an ever-changing concept of a wide variety of methods used by social work and social pedagogy in the school environment, including social counselling, casework, group therapy, community work, etc.

This model quickly established itself in Germany, given the closeness of social pedagogy to social work here thanks to the work of such early pioneers as Bäumer. The compound 
descriptor "social pedagogy/social work" used in Germany to denote the field further evidences this closeness. Some authors, in accordance with their views, would also use the term "school social work", such as Tillmann (1980) and Wulfers (1996). Others such as Böhnisch $(1992,1997)$ and Hopf (2001), loyal to the domestic terminological tradition, prefer "school social pedagogy".

German school social pedagogy has traditionally been interested in elevating the quality of social relationships, the problem of underachievement at school, prevention of truancy and risk-taking behavior, and the development of healthy lifestyles (Böhnisch, 1997). Although school social work/pedagogy had been emphasized in Germany since its inception, this emphasis became even greater in the 1990s with increasing awareness of socially pathological phenomena in children and youth such as addiction, delinquency and bullying. Schools were expected to play a vital role in preventing these problems (starting in the 1990s in the Czech Republic and Slovakia, this problem has been addressed by designating a "prevention methodologist" in every school. Their function was most importantly to coordinate prevention activities and give advice regarding socially pathological behaviors to students, parents and staff in cooperation with the school team. A significantly limiting factor is that the post would be filled by a qualified teacher without impacting the number of hours taught overall. This time constraint made the prevention specialist function a mere formality in many schools). More recently, Rossemeissel and Przybilla (2006) draw attention to the necessity of social pedagogues in schools that focus on the integration of children with special educational needs (SEN). Schools can offer the assistance of social pedagogy to students and their families not only as an integral part of the social services, but also as expert support provided by social pedagogues as designated employees of the school.

In Poland, there is a strong tradition of social pedagogy dating back to the $19^{\text {th }}$ century. While there is no official, state-regulated position called "the social pedagogue" here, the term is commonly used in the academic discourse as a catch-all descriptor for a broad scope of the helping professions (community and social workers, educators, etc). In schools, the performance of the agenda of social pedagogy is up to specially trained workers known as school pedagogues (pedagog szkolny). These are employees of the school who organize both pedagogical and psychological help within the institution. During their university studies, they are prepared for the management of educational and care-giving processes in schools as well as activities outside of them in order to complement and broaden the formal education conducted by teachers. The functions of education, care, diagnostics and counselling are particularly emphasized (Encyklopedia pedagogiczna, 2005, 85). Required qualifications include the study of pedagogy, psychology or social work at university level.

Similarly to Germany, the Polish concept of social pedagogy focuses on social help. This is offered to individuals and groups finding themselves in a variety of problematic, personally difficult and stressful situations, or even at a point of crisis. In this sense, the 
everyday work of the school pedagogue is also understood as a complex of activities with the characteristics of social help (Laurman-Jarząbek, 2005, 134). In the school environment, help is oriented towards facilitating learning for students from deprived backgrounds, coordinating work between institutions dealing with personal development, collaborating with both formal and informal institutions, intervention in individual, group or family problems, as well as coordinating prevention programs and delivering open school services as part of the local environment (Słoma, 2001).

Since the turn of the millennium, social pedagogues (educadores sociales) have been struggling to be included in Spain as well. In some of the autonomous regions, such as Castilla-La Mancha and Extremadura, the social pedagogue is a non-academic employee of the school who focuses on overcoming inequality and on the recognition of individual and social rights in education, along with cooperation with the community, fostering relationships with local actors, mediating and resolving conflict arising from school interactions, and supporting education towards citizenship and solidarity (Castillo Carbonell, 2013). The social pedagogue supports the culture of the school founded on mutual learning and coordinates a number of special programs and projects.

Switzerland has seen developments in social work since the 2000s. According to Gschwind, Ziegele and Seiterle (2014), the German-speaking cantons now employ more than 900 pedagogues in school social work. Some of the issues they deal with include aggression and conflict resolution, the prevention of addiction, also public health, sex education, crisis intervention and early risk detection. They are on call in any setting at the given school, be it the classroom or the staff room, the school itself or its surroundings. They attend meetings with parents and cooperate with experts both within and outside of the school.

The formal delineation of the social pedagogue's remit is ambivalent in Switzerland, however, lacking clarity in terminology applied to the school environment. Several different labels are in use, including "school social work", "social work in schools", "school-accompanying social work", "social work with youth in schools", "socialeducational activity of the school", "youth advice and services in schools" and more. It is also unclear to what extent this refers to educational services such as mental health counselling in schools or special and therapeutic pedagogy, or if it should be understood as a branch of the social services that just happens to be offered to children and youth at school. The literature speaks of both student counselling in terms of personal, educational and social problems, and of special classes and extracurricular activities, including recreational ones. Some authors place particular emphasis on early detection and intervention, along with equalizing social disadvantages. There is some debate on whether school activities should be under the jurisdiction of the cantons and whether they should be couched in social work or in the school system (ibid., 4-5). 
More recently, the UK has shown interest in social pedagogy, although the field does not have a long history there in either theory or practice. The situation is changing now, fuelled by worries about students' performance at GCSE level and leading to the practice of identifying "at risk" students, whose problems and needs are to be solved by social pedagogues (Kyriacou et. al., 2009). A new agenda of "every child matters", along with the perceived need to improve the professional activities of school staff, drew inspiration from the continental practice of social pedagogy, particularly its current forms in Scandinavia and Germany (Cameron et al., 2011).

in the UK, social pedagogy is conceptualized as a means of taking care of the needs of vulnerable children across a broad spectrum of social circumstances. In relation to the school, the agenda of social pedagogy has coalesced around four pillars. First is the issue of academic underachievement, especially in numeracy and literacy. The second area covers problems related to undesirable behavior, truancy and lack of professional ambition. Thirdly it deals with disturbances in psychosocial development, often tied to antisocial behavior, deficits in social skills, and feelings of inadequacy and exclusion. The final issue is the threat to healthy lifestyle posed by nutritional deficiencies (as well as alcohol and drug consumption) or membership in criminal gangs (Kyriacou, 2012).

The activities of school social pedagogues in the UK are based on a unifying concept of the personal, social and educational needs of the child. Intervention is then understood as helping students to develop a positive psychosocial identity and the ability to be their authentic selves, along with supporting students in developing the kind of social and personal competencies that would enable them to integrate and succeed in society.

In the 1990s, the social pedagogue post was implemented in Russia as a result of rising numbers of at-risk children and families. The profession gained particular popularity in institutions focusing on children with socialization problems (boarding schools, orphanages, correctional facilities for children with behavioral disruptions) and in primary schools (Sorochinskaya, 2015). The work of social pedagogues has also become important to the far-flung rural regions of Russia, where the ongoing economic crisis has worsened the problems of the population to the extent that rural communities had begun to disintegrate. The role of social pedagogues (Gurjanova, 2014) lies in organizing everyday social and educational activities with children and their families, fostering partnerships between schools, families, teachers and parents, coordinating interdepartmental cooperation to solve social and educational problems of children and families, and collaborating with other experts in the social and public spheres to secure a comfortable and secure environment for children to live in. The overarching goal is to harmonize the relationships between children and rural societies, to encourage positive socialization and to improve life conditions through professional social and pedagogical work. 
At present, however, there are various difficulties related to expanding the activities of social pedagogy into additional social spheres. The numbers of social pedagogues (but also those of social workers and psychologists) are decreasing in just those areas where problems concerning children, youth and families are on the rise. There are observable tendencies to limit the potential of social pedagogy in favor of mere social control exercised by the school over children with socialization problems (Romm, 2016).

Slovakia, the country that is historically and culturally closest to the Czech Republic, finds itself quite ahead of Czech realities as far as introducing social pedagogy into schools is concerned. In 2009, new legislation formally established the social pedagogue as an expert post appointed by the school. In the central European context, this is a significant development for a state-regulated profession. The professional remit of the social pedagogue mainly addresses the prevention of socially pathological phenomena, social disadvantage and counselling. Paragraph 24 of the aforementioned bill states:

The social pedagogue engages in expert activities geared towards prevention, intervention and counselling provision mainly to children and students who are threatened by socially pathological phenomena or who come from socially disadvantaged backgrounds, as well as legal guardians and pedagogical staff at schools and other educational institutions. The social pedagogue combines the functions of social education, supporting prosocial and ethical behavior, diagnosing the social environment and relationships, counselling, preventing socially pathological phenomena and behavioral re-education. This constitutes expert and educational activity (Bill n. 317/2009, § 24, 14).

The role of the school social pedagogue enjoys a great degree of attention in Slovakia (see e.g. Hroncová, 2011; Niklová, 2014; Határ, 2016). Interestingly, despite the emphasis on pedagogical expertise, the post can also be legally held by Master's level graduates of social work. This brings Slovak practice into contact with the German tradition, in which social pedagogy and social work first converged.

Although each country has developed school social pedagogy in line with its traditions, needs and possibilities, there are more similarities than differences among them. The fact that social pedagogy is gaining ground even in countries where it has a shorter tradition demonstrates that its potential to solve the problematic social situations that accompany school-based education is promising.

\section{Integrating Social Pedagogues into the Czech School System}

The situation in the Czech Republic is specific in that social pedagogy has only significantly developed since the 1990s, but it has been very dynamic during that time. In 1997, it began to be taught as a specialism within pedagogy at some universities. Today, by contrast, there are hardly any humanities faculties that wouldn't offer it as its own field. Social pedagogy is currently accredited at ten faculties across eight public universities, with courses taught on Bachelor's and Master's levels. These faculties include the 
Faculty of Arts at Charles University Prague, the Faculty of Arts and Faculty of Pedagogy at Masaryk University, the Hussite Theological Faculty at Charles University, the Pedagogical Faculty at Hradec Králové University, the Faculty of Humanities at the Tomáš Bat'a University in Zlín, the Cyril and Method Theological Faculty at Palacký University, the Faculty of Pedagogy at Ostrava University, the Faculty of Pedagogy at the University of South Bohemia, and the Faculty of Pedagogy at the J. E. Purkyně University. By 2014, the field had more than 6,500 Bachelor's level graduates and 6,800 Master's level graduates (Moravec et al., 2015, 19). It is also available at a number of private schools, as well as vocational schools with specialisms in social pedagogy.

Despite this substantial rise of social pedagogy, the post has not yet been established in schools on a systemic level. The academic community attempted to have this included in new legislation passed in 200. The result was a parliamentary appeal, thanks to the efforts of prominent figures in the field such as its co-founder B. Kraus, which led to a legal amendment specifying that graduates of social pedagogy could perform certain professions in education (they could now work as pedagogues and extracurricular pedagogues).

Spring 2014 saw a renewed effort on the part of the Association of Educators in Social Pedagogy (AVSP), founded in 2013. The Association, bringing together representatives of university departments that educate social pedagogues, aims to develop social pedagogy as a scientific field of study, to articulate educational standards for the field, to campaign for the inclusion of the social pedagogue as a profession in school legislation, and to support the establishment of the profession in the social sphere at the same time (AVSP, 2013). Members of the Executive Board of the Association produced a report after discussions with the broader membership in order to provide a source for further debate on the proposed reform on Act no. 563/2004 Sb. On pedagogical workers. The authors argue that

Schools and educational institutions [,,,] are responsible as institutions of socialization for creating appropriate conditions for education and upbringing, but their current professional make-up cannot adequately reflect and react to all the impulses coming from the familial, local and marco-social environment. Therefore we believe it is necessary to involve the profession of the social pedagogue among pedagogical workers as set out in paragraph 2.2 of the Act on pedagogical workers (AVSP, 2014).

However, the profession of the social pedagogue has still not been included in the legislation. This situation is made all the more paradoxical by the fact that graduates of the field have been able to work in the social sphere since January 2007 under Act no. 108/2006 Sb. On social services. 


\section{Introducing Social Pedagogues into Schools: Research and Scenarios}

We have shown that the efforts to officially establish social pedagogues in the Czech school system have largely been unsuccessful in previous years. More recently, however, the situation has started changing. In 2015, a collective of authors (Moravec et. al., 2015) produced a document for the Ministry of Education titled "The Introduction of the Social Pedagogue into Schools: A Feasibility Study". This analysis, commissioned officially by the Ministry, provided a detailed look at the readiness of the Czech education system for the creation of this post, and concluded that it would be unequivocally beneficial to introduce it. Among other points, the authors mentioned that if schools are better equipped to fulfill their socially pedagogical role as a result of introducing a specialist post, they can become centers of social prevention in the future, strengthening social cohesion in their communities (Moravec et. al., 2015, 75).

Many of the study's arguments were based on those articulated by the Association of Educators. The authors also pointed out the projected rise in the numbers of students in the coming decade, remarking that the more crowded schools are, the greater the problems associated with the social climate of the school, relations in the classroom and between teachers and students, as well as issues such as truancy (Moravec et. al., 2015, 7). To manage these problems, the authors recommend recruiting additional school staff. They also consider it appropriate to establish the post of the social pedagogue as a new distinct profession in the school system.

The study related its recommendations to the findings of other research, such as that carried out at Masaryk University in Brno as part of EU projects funded by the Operational Program for Education Towards Competitiveness. The most significant findings come from a project titled "Creativity and Innovation in Educational Programs and Professional Practices". A total of 20 social pedagogues and final year students of the field at Masaryk University worked at 12 schools in the region of South Moravia in 2012 (11 primary schools and one secondary, a grammar school). The project presupposed working with students for about four hours a week, but the researchers spent significantly more time at the given school overall. Subsequent analysis of data gathered during the project showed that social pedagogues, even within such a temporary arrangement, found their niche and were positively evaluated by the existing team. All principals and their deputies surveyed in the study expressed complete satisfaction with the work of these social pedagogues, even in cases where they had not initiated the project themselves (Moravec et. al., 2015, 30).

The feasibility study also outlined several possible scenarios for introducing the social pedagogue into schools (ibid., 75-76):

- Making the post compulsory across all primary and secondary schools. The authors consider this the ideal scenario, but less realistic due to the financial burden it imposes. 
- Making the post compulsory in schools considered to be at risk. This measure would not, however, contribute to a more even distribution of the population of disadvantaged children.

- Offering to institutionalize the post on a global scale, but leaving the decision to the individual schools. The risk in this scenario is that the offer may not be taken up by precisely those schools which would most benefit from introducing a social pedagogue to increase the inclusiveness of their environment, as they may not be aware that they have a problem to be solved. Schools that consciously resist including socially disadvantaged children would ignore it as well.

- Establishing the post based on regional needs and leaving the division of financially supported positions up to voluntary coordination by the schools. This type of intervention runs the risk of using up financial resources in less motivated schools at the expense of better prepared, more motivated ones located outside the designated geographical area.

Due to the costs associated with introducing the post globally, the authors have recommended the last two scenarios to be prioritized. At the same time, they warned against allocating funds to schools simply for establishing the post of the social pedagogue for a year or two, after which the project would end and no more funding provided. The work of social pedagogues in schools is only meaningful if it is continuous in the long term.

\section{Social Pedagogues As Personal Support in EU School Projects}

One of the key domains of assistance in social pedagogy is support for socially disadvantaged children and their families. In the Czech Republic, the situation of the Roma community is particularly alarming, as the school system has mainly just kept the status quo rather than attempting to facilitate its advancement. In 2012, the OECD report Equity and Quality in Education: Supporting Disadvantaged Students and Schools made critical comments about the Czech education system reproducing social stratification rather than making any significant steps to include disadvantaged children into the mainstream and create the conditions necessary for their success in the job market and in terms of upward mobility (OECD, 2012). These conclusions are further confirmed by the yearly report on the state of the Roma minority discussed by the government, indicating a long-term unsatisfactory state. On $11^{\text {th }}$ May 2016, these facts culminated in the Governmental Resolution on the Integration of the Roma Minority, which obliges the Minister for Education to outline the activities and professional qualifications of social pedagogues, to standardize their education, to legally define the post and to secure its funding by 2019 (Czech Government, 2016, 5).

The Ministry of Education has made it possible for the first time in history for kindergartens and primary schools to request funding to finance the post of the social 
pedagogue (as well as school psychologist, special pedagogue, pedagogical assistant etc) from the European Structural and Investment Funds in the 2014-2020 period. This means that the social pedagogue has finally been included by the Ministry on the official list of positions that can offer assistance to schools in addressing the threats to students' achievement. When identifying at-risk children, schools have been recommended to look for low motivation for education, long-term underachievement in grades, insufficient preparation for lessons, behavioral issues, lack of familial authority, social disadvantage, etc. If a school wishes to request funding, it must identify at least three students in these situations.

Considering that many principals of Czech schools are not sufficiently aware of what can be expected of social pedagogues in school-based practice, a relatively detailed job description has been provided by the Ministry (MŠMT, 2016, 63-66):

- Social pedagogues create better conditions for establishing contacts and beneficial relationships with families, as well as facilitate expert support such as counselling and health from relevant institutions. In this context they provide social and legal advice, social therapy, and information for other academic staff regarding the domestic environment of students in order to determine the most suitable approach.

- They concentrate on early detection of children vulnerable to isolation, abuse, neglect, pathological social phenomena and crime. This includes the school's cooperation with municipalities, health institutions, the police and the courts, state representatives and other relevant organizations that can contribute to resolving the issues facing these children.

- Within the school, they coordinate career counselling with input from headteachers, other pedagogues, classroom assistants, students, parents, job centers, and employment agencies. They also manage mentoring schemes, excursions, lectures and open days, and assist socially disadvantaged students with access to secondary education.

- They collaborate on projects focused on the prevention of pathological phenomena in society, which includes students' personal development and civic education.

- They coordinate volunteers who run remedial lessons (in primary schools only), strengthen the community dimension of the school and educate other pedagogues on relevant social issues.

Although the current situation can be considered a great leap forward, it is clear that without legislative support, the position of social pedagogues in schools would be very weak and likely to be eliminated after the duration of any given project. It is therefore a positive development that social pedagogues are finally being included in the revised bill on pedagogical workers, two long decades after the field of social pedagogy was first 
unveiled by Czech universities. Even this progress has its negative aspects, such as the fact that the law only comes into force on $1^{\text {st }}$ September 2021, when it will no longer be possible to take advantage of EU funding in this area. Paradoxically, the very funds that have made it possible to incorporate the role of the social pedagogue into the school are now at the center of a potential complication to the entire process.

\section{Conclusion and Discussion}

There is no doubt that the process of introducing social pedagogy into schools by means of qualified workers has been slow and complicated in the Czech Republic. In the past it was significantly hindered by fears of the financial strain of establishing such a post. Although some schools had managed to secure funding for social pedagogues, these initiatives were few and far between, and they depended on the open-mindedness of the school's management. The current positive shift has been caused by a variety of factors.

International criticism contributed to a heightened awareness of equal approaches to preschool, primary and secondary education levels in educational policy. It was then necessary to focus on the problem of social disadvantage as a key cause of underachievement at school.

Funding available from the European Structural and Investment Funds was also crucial. Last but not least, we must mention the activities of academics and the Association of Educators in Social Pedagogy, NGO lobbying and the successful careers of thousands of graduates of social pedagogy and their work with children and youth in practice. They can be considered professionally qualified experts whose potential is waiting to be unleashed.

Despite these evident changes for the better, there is still the question of how the process of integrating social pedagogues into Czech schools may turn out. A number of risks have been identified in this context. Senior school employees are still insufficiently informed of the advantages of having social pedagogues at their school. It is therefore necessary to organize systematic education and onboarding in this regard, for instance by round-table discussions, professional seminars and shared examples of good practice.

There is a lack of consistent cooperation between the decision-making sphere and the academic public, especially the universities educating social pedagogues. The fact that it has been necessary to establish a separate society (the aforementioned Association of Educators in Social Pedagogy) in order to promote the public's demands shows that academia is still not considered relevant to addressing these questions by governmental institutions.

Not all academic issues are discussed sufficiently. For instance, in a proposal to update the legislation dealing with pedagogical workers, completion of Master's level study of social pedagogy is the qualification prerequisite for being appointed a school social pedagogue. Under the current European framework, however, Master's level graduates of social work can likewise work in this capacity. There is some doubt regarding the 
extent to which these graduates possess the required pedagogical competencies if their education lacks any pedagogical disciplines. Unity of social work and social pedagogy as in the German model or more recently in Slovakia is of course possible, but it is necessary for these fields to be open to mutual cooperation in the Czech Republic as well.

The fate of the legislation that would update the law on pedagogical workers, related to a historic first draft outlining the career progression of teachers, is also uncertain, as it has become a subject of criticism and finds itself in the midst of political struggle in the Czech Republic. With an election currently upcoming, the proposed amendments to the bill now cannot be expected to be passed.

Aside from the aforementioned problems, the process is also disrupted by the competition between the Ministry of Education and the Ministry of Social Affairs, with the latter trying to take over the issue of at-risk children and youth. How this potential shift would influence the situation of school social pedagogues is, at the moment, impossible to tell.

\section{References}

AVSP (2013). Stanovy Asociace vzdělavatelů v sociálni pedagogice (By-laws of the Association of Educators of Social Pedagogy). Archiv autorky.

AVSP (2014). Návrh na zařazení profese sociálniho pedagoga do zákona č. 563/2004 Sb. o pedagogických pracovnících. Zdůvodñující zpráva (Proposal of the introduction of the profession of a social pedagogue to the law no. 563/2004 regarding pedagogical workers). Archiv autorky.

BÄUMER, G. (1929). Die historischen und sozialen Voraussetzungen der Sozialpädagogik und die Entwicklung ihrer Theorie. In Nohl, H. \& Pallat, L. (Hrsg.) Handbuch der Pädagogik. Bd. 5: Sozialpädagogik (3-17). Langensalza: Beltz.

BÖHNISCH, L. (1992). Sozialpadagogik des Kindes- und Jugendalters. Weinheim - München: Juventa Verlag.

BÖHNISCH, L. (1997). Sozialpädagogik der Lebensalter. Eine Einführung. Weinheim - München: Juventa Verlag.

CAMERON, C., PETRIE, P., WIGFALL, V., KLEIPOEDSZUS, S., \& JASPER, A. (2011). Final report of the social pedagogy pilot programme: development and implementation. London: Institute of Education [online].[cit. 2017-04-21]. Available from http://www.ioe.ac.uk/study/departments/tcru/4804.html.

CASTILLO CARBONELL, M. (2013). La aportación de los educadores y educadoras sociales a la escuela: nuevas competencias, nuevas posibilidades. Revista de Educación Social, no. 16, 1-11.

Encyklopedia pedagogiczna XXI wieku (2005). Warszawa: Wydawnictwo Akademickie „Żak”.

GURJANOVA, M. P. (2014). Barery na puti razvitija instituta socialnych pedagogov $v$ selskich rajonach Rossiji (Барьеры на пути развития института социальных педагогов в сельских районах России; Barriers in the course of development of the position of social pedaguges in rural regions of 
Russia). Проблемы современного образования [online]. 1, 31-40 [cit. 2017-01-13]. Available from WWW: http://www.pmedu.ru

GSCHWIND, K., ZIEGELE, U., \& SEITERLE, N. (2014). Soziale Arbeit in der Schule. Definition und Standortbestimmung. Luzern: Interact Verlag Hochschule Luzern.

HÄMÄLÄINEN, J., \& ERIKSSON, L. (2016). Social Pedagogy in Finland and Sweden: A Comparative Analysis. Pedagogia Social. Revista Interuniversitaria, no. 27, 71-93.

HATÁR, C. (2016). Sociálny pedagóg ako aktér triednej a školskej klímy (Social pedagogue as a factor of the school and classroom climate). Slavonic Pedagogical Studies Journal, 5(2), 206-216.

HEGSTRUP, S. (2003). Tendencies and Trends in Social Pedagogy in Denmark at the Turn of the Millennium. In Gustavsson, A., Hermansson, H., \& Hämäläinen, J. (Eds.) Perspectives and Theory in Social Pedagogy (72- 83). Goteborg: Daidalos.

HOPF, A. (2001). Sociální pedagogika ve škole (Social pedagogy in school). Praha: Pedagogická fakulta UK.

HRONCOVÁ, J. (2011). Spolupráca inštitúcií verejnej správy so školami v oblasti prevencie sociálnopatologických javov $\mathrm{s}$ osobitným zretel'om na uplatnenie sociálnych pedagógov (Cooperation of the public administration institutions with schools in regards to prevention of socially pathological phenomena with a special consideration to the employment of social pedagogues). In Zborník vedeckovýskumných prác Katedry pedagogiky, č. 7. Banská Bystrica: PF UMB.

KORNBECK, J., \& ROSENDAL JENSEN, N. (Eds.) (2009). The diversity of Social Pedagogy in Europe. Studies in Comparative Social Pedagogies and International Social Work and Social Policy, Vol. VII (211- 235). Bremen: Europäischer Hochschulverlag.

KORNBECK, J., \& ROSENDAL JENSEN, N. (Eds.) (2012). Social pedagogy for the entire lifespan. Studies in Comparative Social Pedagogies and International Social Work and Social Policy, Vol. XVIII (1-8). Bremen: Europäischer Hochschulverlag.

KORNBECK, J., \& ÚCAR, X. (Eds.). (2012). Latin American Social Pedagogy: relaying concepts, values and methods between Europe and the Americas. Studies in Comparative Social Pedagogies and International Social Work and Social Policy, Vol. XXVIII. Bremen: Europäischer Hochschulverlag.

KYRIACOU, C. (2012). The role of social pedagogy and civic engagement in helping troubled 14-year-olds. Psychology of Education Review, 36(1), 44-47.

KYRIACOU, C., ELLINGSEN, I. T., STEPHENS, P., \& SUNDARAM, V. (2009). Social pedagogy and the teacher: England and Norway compared. Pedagogy, Culture \& Society, 17(1), 75-87. https://doi.org/10.1080/14681360902742902

LAURMAN-JARZĄBEK, E. (2005). Udział pedagoga szkolnego w pracy opiekuńczo-wychowawczej szkoły. In Matyjas, B. (red). Problemy teorii i praktyki opiekuńczej. Kielce: Wydawnictwo Akademii Świętokrzyskiej.

MORAVEC, Š., KABELOVÁ, K., HŮLE, D., \& ŠŤASTNÁ, A. (2015). Zavedení pozice sociálního pedagoga do škol (Introduction of the social pedagogue position to schools). Plzeň: Společnost Tady a ted', o.p.s., Demografické informační centrum, o.s. 
MŠMT (2016). Přehled šablon a jejich věcný výklad. Operační program Výzkum, vývoj a vzdělávání (List of templates and their factual interpretation) [online]. [cit. 2017-04-20]. Available from WWW: http://www.msmt.cz/uploads/OP VVV/vyzva sablony I/Avizo kveten 2016/Prehled sablo $\underline{\mathrm{n} \text { avizo.pdf }}$

NIKLOVÁ, M. (2013). Profesijné kompetencie a špecifiká pôsobenia sociálnych pedagógov $v$ školách (Professional competencies and specific functioning of social pedagogues in schools). Banska Bystrica: UMB.

OECD (2012). Equity and Quality in Education: Supporting Disadvantaged Students and Schools [online]. [cit. 2015-02-13]. Available from WWW: http://dx.doi.org/10.1787/9789264130852-en

PETRIE, P. (2013). Social Pedagogy in the UK: Gaining a firm foothold? Education Policy Analysis Archives [online]. 21(37) [cit. 2007-06-13]. Available from WWW: http://epaa.asu.edu/ojs/article/view/1339

ROMM, T. (2016). The development of Social Pedagogy in Russia. Pedagogía Social. Revista Interuniversitaria, no 27, 133-152.

ROSSEMEISSEL, D.; \& PRZYBILLA, A. (2006). Schulsozialpädagogik. Bad Heilbronn: Klinkhardt.

SŁOMA, M. (2001). Nowa rola pedagoga szkolnego. Edukacja i dialog, no. 6, 44-47.

SOROCHINSKAYA, E. (2015). Social pedagogy in Russia: trends, problems, ideas. $R$ zeknes Augstskola, no. 3, 399-406. DOI: http://dx.doi.org/10.17770/sie2015vol3.359

TILLMANN, K.-J. (1980). Schulsozialarbeit. In Kreft D., \& Mielenz, I. Wörterbuch Soziale Arbeit. Weinheim - Basel: Beltz.

TILLMANN, K.-J., Hg. (1982). Schulsozialarbeit. Problemfelder ud Erfahrungen aus der Praxis. München: Juventa.

VLÁDA ČR (2013). Usnesení Vlády ČR ze dne 11. května 2016 č. 416 k Revizi úkolů vyplývajících z usnesení vlády, týkajících se integrace romské menšiny (Decree of the Government of the Czech Republic from $11^{\text {th }}$ May 2016 no. 416 regarding Revision of tasks resulting from the governmental decree, concerning the integration of the Romani minority). Available from WWW: http://docplayer.cz/36476096-Usneseni-vlady-ceske-republiky-ze-dne-11-kvetna-2016-c-krevizi-ukolu-vyplyvajicich-z-usneseni-vlady-tykajicich-se-integrace-romske-mensiny.html

WULFERS, W. (1996). Schulsozialarbeit. Ein Beitrag zur Öffnung, Humanisierung und Demokratisierung der Schule. Hamburg: AOL Verlag.

Zákon č. 317/2009 z 24. júna 2009 o pedagogických zamestnancoch a odborných zamestnancoch a o zmene a doplnení niektorých zákonov (Law no. 317/2009 from 24th June 2009 about pedagogical employees and about change and revision of some laws). Available from WWW: http://www.zakonypreludi.sk/zz/2009-317

Zákon č. 108/2006 Sb., o sociálních službách, ve znění pozdějších předpisů (Law no. 108/2006, in the sense of later regulations). Available from WWW: https://www.zakonyprolidi.cz/cs/2006-108 